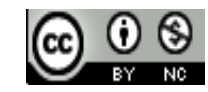

Jurnal Bimbingan Konseling Indonesia is licensed under

A Creative Commons Attribution-Non Commercial 4.0 International License.

\title{
PROBLEMATIKA PEMBERDAYAAN GURU BIMBINGAN KONSELING DI SEKOLAH
}

\author{
Syamsul Huda ${ }^{1)}$, Rusmini $^{2)}$, Nurlia Siregar ${ }^{3)}$ \\ 1) Universitas Islam Negeri Sulthan Thaha Saifuddin jambi, Jambi, Indonesia \\ E-mail: syamsulhuda@uinjambi.ac.id. \\ 2) Universitas Islam Negeri Sulthan Thaha Saifuddin jambi, Jambi, Indonesia \\ E-mail:rusmini@uinjambi.ac.id \\ 3) Universitas Islam Negeri Sulthan Thaha Saifuddin jambi, Jambi, Indonesia \\ E-mail: NurlyaSiregar95@gmail.com
}

\begin{abstract}
Abstrak. Guru bimbingan konseling memiliki peranan penting dalam konseling, bimbingan untuk mengembangkan minat dan bakat siswa, serta bimbingan dalam mengembangkan kepribadian siswa. Namun, dalam praktiknya guru Bimbingan Konseling tidak diberdayakan dengan baik. Hal ini terlihat dari pelaksanaan bimbingan yang tidak sesuai jadwal dan kurang adanya program peningkatan profesionalitas guru Bimbingan Konseling. Penelitian ini bertujuan untuk mengetahui faktor dibalik problematika pemberdayaan guru bimbingan konseling di Sekolah. Penelitian dilakukan secara kualitatif deskriptif dengan menggunakan metode observasi, wawancara, dan dokumentasi. Hasil penelitian menunjukan bahwa Pemberdayaan guru bimbingan konseling berjalan kurang efektif mulai dari perencanaan, pengorganisasian, pelaksanaan, dan evaluasi. Faktor penyebab diantaranya adalah karena kurangnya fasilitas dan anggaran, terbatasnya waktu bimbingan, kepala sekolah dan komite sekolah kurang memahami peran dan tugasnya dalam mendukung program peningkatan profesionalitas guru Bimbingan Konseling. Masalah tersebut dapat diatasi melalui kebijakan dan manajemen yang dilakukan Kepala Sekolah serta dukungan dari berbagai pihak.
\end{abstract}

Kata Kunci: Problematika; Pemberdayaan; Bimbingan Konseling

\section{PENDAHULUAN}

Pendidikan nasional bertujuan untuk memberi bekal kepada peserta didik berupa pengembangank kognitif, afektif, dan psikomotor. Namun, harus dipahami bahwa peserta didik merupakan individu dengan karakter yang unik dan dinamis. Peserta didik memiliki kemampuan, minat, dan bakat yang berbeda. Sekolah berperan sebagai agen sosialisasi dalam pembentukan moral peserta didik yang didapat melalui pembiasaan, hukuman, penghargaan, keteladanan, dan kualifikasi kegiatan siswa [1], [2], [3]. Sebagai individu yang tumbuh dan berkembang, tidak bisa dipungkiri bahwa siswa mengalami berbagai permasalahan. Permasalahan tersebut dapat diatasi melalui kegiatan bimbingan dan konseling yang dilakukan di Sekolah [4]. Kegiatan bimbingan dan konseling terdiri dari dua kegiatan yaitu kegiatan bimbingan dan kegiatan konseling.
Kegiatan bimbingan merupakan kegiatan yang memberikan bantuan kepada individu dalam menghadapi persoalan hidup peserta didik. Bantuan yang tepat akan berdampak pada berkembangnya kemampuan siswa [5]. Secara etimologis kata bimbingan merupakan terjemahan dari kata "Guidance" berasal dari kata kerja "to guide" yang berarti menunjukkan, membimbing, menuntun, ataupun membantu. Sesuai istilah tersebut, bimbingan dapat diartikan sebagai suatu bantuan, atau tuntunan, namun tidak semua bentuk bantuan atau tuntunan adalah bimbingan [6] Bimbingan juga berarti bantuan yang diberikan oleh seseorang laki-laki ataupun perempuan yang memiliki kepribadian memadai dan terlatih dengan baik terhadap individu setiap usia untuk membantunya mengatur kegiatan hidup, mengembangkan pandangan hidup, membuat keputusan sendiri dan menanggung bebannya sendiri [7]. Bimbingan juga berarti suatu proses pemberian bantuan kepada individu, dilakukan secara berkesinambungan, agar 
individu tersebut dapat memahami dirinya sendiri sehingga dia sanggup mengarahkan dirinya dan dapat bertindak wajar sesuai norma yang berlaku.

Konseling sendiri berasal dari bahasa Inggris " to counsel" yang secara etimologis berarti "to give advice" yang artinya memberi saran dan nasehat. Konseling adalah sebuah bentuk hubungan pribadi yang dilakukan secara tatap muka antara dua orang. Konselor dengan kemampuan khusus yang dimilikinya menyediakan situasi belajar sementara konseli dibantu untuk memahami dirinya sendiri, keadaannya sekarang, dan kemungkinan keadaannya di masa yang akan datang yang ia ciptakan dengan potensi yang ia miliki, untuk kesejahteraan pribadi maupun masyarakat. Konseli belajar tentang proses memecahkan masalah dan menemukan kebutuhan yang akan datang [8]. Menurut Tohirin [9] ada beberapa pelayanan bimbingan konseling di sekolah, yaitu:

1) Orientasi, merupakan layanan yang diberikan kepada peserta didik agar peserta didik dapat memahami lingkungan baru, terutama lingkungan sekolah/madrasah dan obyek yang dipelajari. Bantuan ini bertujuan agar peserta didik dapat menyesuaikan diri sehingga mempermudah, dan memperlancar peserta didik dalam menjalani perannya di lingkungan yang baru.

2) Informasi, yaitu layanan yang diberikan kepada peserta didik agar mampu menerima dan memahami berbagai informasi tentang diri sendiri, sosial, belajar, karir/jabatan, dan pendidikan lanjutan.

3) Penempatan dan Penyaluran, yaitu layanan diberikan kepada peserta didik untuk memperoleh penempatan dan penyaluran yang tepat di dalam kelas, kelompok belajar, jurusan/program studi, program latihan, magang, dan kegiatan ekstra kurikuler sesuai dengan minat dan bakatnya.

4) Penguasaan Konten, yaitu layanan yang diberikan kepada peserta didik untuk menguasai konten tertentu, terumata kompetensi dan atau kebiasaan yang digunakan dalam kehidupan di sekolah, keluarga, dan masyarakat.

5) Konseling Perorangan, yaitu layanan yang diberikan kepada peserta didik untuk memecahkan masalah pribadinya.

6) Bimbingan Kelompok, yaitu layanan yang diberikan kepada peserta didik untuk mengembangkan diri, mengembangkan kemampuan hubungan sosial, kegiatan belajar, karir/jabatan, dan pengambilan keputusan, serta melakukan kegiatan tertentu melalui dinamika kelompok.

7) Konseling Kelompok, yaitu layanan yang diberikan kepada peserta didik untuk membahas dan mengentaskan masalah pribadi melalui dinamika kelompok.

8) Konsultasi, yaitu layanan yang diberikan kepada peserta didik dan atau pihak lain dalam memperoleh wawasan, pemahaman, dan cara-cara yang perlu dilaksanakan dalam menangani kondisi dan atau masalah peserta didik.
9) Mediasi, yaitu layanan yang diberikan kepada peserta didik untuk menyelesaikan permasalahan dan memperbaiki hubungan antar peserta didik.

Pelayanan bimbingan konseling di sekolah secara umum dapat didefenisikan sebagai usaha untuk membantu peserta didik mengembangkan kehidupan pribadi, sosial, kegiatan belajar serta perencanaan dan pengembangan karir [10]. Pelayanan tersebut dapat dikelompokkan menjadi beberapa bidang yaitu:

1) Bimbingan Akademik, Bimbingan akademik merupakan bimbingan yang diberikan untuk menemukan cara belajar yang tepat, memilih program studi yang sesuai, dan mengatasi kesukaran-kesukaran yang timbul dalam pembelajaran di institusi pendidikan

2) Bimbingan Sosial Pribadi, Bimbingan sosial pribadi merupakan bimbingan untuk membantu individu memecahkan masalah sosial pribadi, seperti masalah hubungan dengan sesama teman dengan guru dan staf, pemahaman sifat dan kemampuan diri, penyesuaian diri dengan lingkungan pendidikan dan masyarakat tempat tinggal, dan penyelesaian konflik.

3) Bimbingan Karir, Bimbingan karir merupakan bimbingan untuk membantu individu dalam merencanakan, mengembangkan, dan memecahkan masalah seputar seperti: pemahaman terhadap jabatan dan tugas kerja, pemahaman kondisi dan kemampuan diri, pemahaman kondisi lingkungan, perencanaan, dan pengembangan karir, serta penyesuaian pekerjaan dan pemecahan masalah karir yang dihadapi.

4) Bimbingan Keluarga, Bimbingan keluarga merupakan pemberian bantuan kepada individu untuk memahami peran mereka sebagai pemimpin/anggota keluarga. Pemahaman tersebut diperlukan agar mereka mampu menciptakan keluarga yang utuh dan harmonis, produktif memberdayakan diri, dapat menciptakan dan menyesuaikan diri dengan norma keluarga, serta berperan aktif dalam perwujudan keluarga bahagia [11].

Mengingat pentingnya manfaat kegiatan bimbingan dan konseling, maka guru yang melaksanakan kegiatan ini perlu diberdayakan dengan tepat. Namun kenyataannya, pemberdayaan guru bimbingan dan konseling mengalami berbagai kendala, misalnya kegiatan bimbingan yang tidak sesuai jadwal dan tidak adanya program peningkatan profesionalitas guru BK. Problematika tersebut juga dihadapi oleh Madrasah Aliyah Negeri (MAN) 3 Kota Jambi. Sehingga dilakukan penelitian untuk mengetahui faktor penyebab munculnya problematika pemberdayaan guru bimbingan konseling di MAN 3 Kota Jambi.

\section{METODE}

Penelitian dilakukan dengan menggunakan pendekatan kualitatif. Metode yang digunakan adalah deskriptif kualitatif. Penelitian dilakukan di MAN 3 Kota Jambi yang beralamat di Jalan Marene Ekajaya Selincah. Subjek dalam 
penelitian adalah Kepala Sekolah, guru bimbingan dan konseling, Wakil Kepala Sekolah Bidang Kesiswaan, Kepala Bagian Tata Usaha, Guru, dan Siswa Madrasah Aliyah Negeri 3 Kota Jambi. Data dalam penelitian ini terdiri dari data primer yang didapatkan langsung dari informan serta data sekunder berupa data tulisan maupun dokumentasi yang telah diolah sebelumnya. Data dikumpulkan melalui observasi (pengamatan), wawancara (interview), dokumentasi. Data di analisis menggunakan analisis berikut :

\section{Analisis domain}

Menurut Sugiyono [12], analisis ini bertujuan untuk mendapatkan gambaran yang umum dan menyeluruh tentang situasi sosial yang diteliti atau objek penelitian. Analisis ini digunakan untuk menganalisis data tentang gambaran umum pemberdayaan guru bimbingan dan konseling di MAN 3 Kota Jambi.

\section{Analisis taksonomis}

Analisisi taksonomis adalah analisis lanjutan untuk mengetahui hubungan antara komponen [13], yang dalam hal ini adalah komponen dalam konteks pemberdayaan guru bimbingan konseling di MAN 3 Kota Jambi.

\section{Analisis Komponensial}

Analisis ini dilakukan setelah analisis domain dan taksonomi untuk menjawab problematika pemberdayaan guru bimbingan konseling di MAN 3 Kota Jambi.

Keabsahan data diperiksa melalui tiga triangulasi yaitu triangulasi sumber, teknik, dan waktu. Penelitian dilakukan November 2017 hingga Juni 2018

\section{HASIL DAN PEMBAHASAN}

Berdasarkan temuan di lapangan, terlihat bahwa Pemberdayaan guru bimbingan konseling di MAN 3 Kota Jambi sudah berjalan namun masih kurang efektif. Pelaksanaannya belum berdasarkan jadwal yang ditetapkan serta belum adanya peningkatan kualifikasi pendidikan guru Bimbingan Konseling. Pemberdayan yang kurang efektif ini dapat dilihat dari beberapa proses berikut

\section{Perencanaan}

Perencanaan untuk kegiatan pemberdayaan guru bimbingan konseling diantaranya adalah melalui penganggaran, penetapan tujuan kegiatan, dan persiapan komponen kegiatan seperti analisis kondisi dan situasi sekolah, strategi layanan, waktu, tempat, dan fasilitas. Perenencanaan belum dilakukan dengan efektif karena sarana dan prasarana dan tidak memadai.

\section{Pengorganisasian}

Pengorganisasian pada bidang bimbingan konseling terlihat dalam proses pembagian tugas personil. Pada saat sosialisasi, beberapa guru bimbingan konseling tidak dapat hadir karena mendapatkan tugas lain yang beriringan. Pemberian tugas juga tidak disesuaikan dengan bidang keahlian guru yang bersangkutan. Pengorganisasian menjadi hal yang penting karena banyaknya permasalahan siswa menimbulkan kepedulian guru Bimbingan dan Konseling dalam melayani siswa. Guru harus mampu bertindak tepat sesuai dengan kemampuannya [14].

\section{Pelaksanaan}

Pelaksanaan Bimbingan dan Konseling menjadi kurang efektif karena kurangnya sarana dan prasarana serta kurangnya anggaran untuk kegiatan Bimbingan dan Konseling. Selain itu, karena pemberian tugas bimbingan konseling bukan pada ahlinya menjadi kegiatan konseling menjadi tidak efektif terutama dalam membimbing siswa menyelesaikan masalah yang dihadapinya

\section{Evaluasi}

Berdasarkan wawancara dengan Kepala Sekolah dan guru di MAN 3 Jambi diketahui bahwa kegiatan evaluasi telah dilakukan namun tidak banyak masukan yang dapat diterima. Hal ini merupakan efek dari kurang efektifnya kegiatan sebelumnya yaitu perencanan, pengorganisasian, dan pelaksanaan.

Berdasarkan uraian proses yang dijelaskan sebelumnya maka dapat dirumuskan Problematika pemberdayaan guru bimbingan konseling disebabkan oleh beberapa faktor, yaitu

\section{Perekrutan guru bimbingan konseling yang tidak sesuai bidang keahlian}

Berdasarkan wawancara dengan guru di MAN 3 Kota Jambi, diketahui bahwa perekrutan guru bimbingan konseling yang tidak ahli dalam bidang konseling menyebabkan tidak efektifnya kegiatan bimbingan konseling di sekolah. Walaupun pihak sekolah berharap melalui perekrutan, guru dapat lebih memahami tugasnya namun tentunya dibutuhkan dukungan dari pihak lain. Hal ini akan terkait dengan pengorganisasian bimbingan untuk pembagian tugas, peranan, dan tanggung yang tegas pada pelaksananya[15].

\section{Kurangnya sarana dan prasarana}

Pelaksanaan bimbingan konseling di Sekolah menjadi kurang efektif karena tidak adanya ruangan khusus untuk melakukan Bimbingan dan Konseling, ruangan yang masih bergabung dengan ruangan UKS (Unit Kesehatan Sekolah) menjadikan kegiatan Bimbingan dan Konseling harusnya bersifat rahasia masih sulit diterapkan. Menurut Kamaluddin [10] pemberian fasilitas dan ruang gerak yang lebih luas serta memberikan otonomi pada guru bimbingan konseling dapat menjadi solusi untuk permasalahan pemberdayaan guru bimbingan konseling di Sekolah. Selain itu, dalam Bimbingan dan Konseling sangat diperlukan asas keterbukaan baik dari pihak konselor maupun pihak konseli agar siswa dapat berbicara secara jujur dan berterus terang serta terbuka menerima saran yang diberikan, ruang yang tidak cukup tentunya dapat mengganggu terlaksananya kegiatan tersebut. 


\section{Terbatasnya jam pelajaran bimbingan konseling}

Bimbingan dan Konseling merupakan kegiatan yang penting di Sekolah karena berperan dalam penyelesaian masalah siswa serta berperan dalam upaya peningkatan prestasi dan minat siswa [17], [18]. MAN 3 Kota Jambi hanya memiliki 1 orang guru bimbingan konseling dengan jam pelajaran yang sangat terbatas dan jumlah siswa yang cukup banyak yaitu berjumlah 426 orang. Kurangnya jam tatap muka untuk bimbingan konseling menjadikan kegiatan ini tidak efektif [19].

4. Kepala Sekolah dan Komite Sekolah kurang memahami peran dan tugasnya dalam mendukung program peningkatan profesionalitas guru bimbingan konseling

Dukungan dari berbagai pihak tentunya penting untuk terselenggaranya kegiatan Bimbingan dan Konseling yang efektif. Kepala Sekolah dan Komite Sekolah diharapkan dapat memberikan dukungan untuk peningkatan profesionalitas guru bimbingan konseling, seperti pemberian pelatihan, peningkatan kerjasama dalam penyelesaian permasalahan siswa dan dukungan dana. Kepala sekolah berperan sebagai coordinator, penyedia sarana dan prasarana, pengawas, pelaksana program, dan penanggung jawab[20], komite sekolah berperan dalam memberikan saran dan dukungan untuk program tersebut.

Permasalahan kurang efektifnya pemberdayaan guru bimbingan konseling dapat diatasi dengan adanya dukungan berbagai pihak seperti Kepala Sekolah, Komite Sekolah, Guru, Orang tua Siswa, dan Pihak lainnya. Selain itu, penambahan jumlah guru bimbingan konseling di MAN 3 Kota Jambi juga dapat menjadi solusi.

\section{IV.KESIMPULAN}

Berdasarkan penelitian yang dilakukan dapat disimpulkan bahwa guru bimbingan konseling di MAN 3 Kota Jambi sudah diberdayakan namun belum efektif. Pemberdayaan yang belum efektif dapat dilihat dari proses perencanaan, pengorganisasian, pelaksanaan, dan evaluasi. Faktornya adalah perekrutan bukan menurut keahlian, kurangnya sarana dan prasarana, terbatasnya jam bimbingan konseling, dan kurangnya pemahaman Kepala Sekolah dan Komite Sekolah untuk mendukung adanya program peningkatan profesionalitas guru.

\section{DAFTAR PUSTAKA}

[1] Agus, A.A. (2010). Degradasi Moral di Kalangan Peserta Didik di SMA Negeri 1. Jurnal Sosialisasi Pendidikan Sosiologi-FIS UNM, 1963, 19-27.

[2] Titin, Nuraini, \& Supriadi. (2014). Peran Sekolah Sebagai Agen Sosialisasi dalam Pembentukan Kepribadian Akhlak Mulia Siswa SMAS. Jurnal Pendidikan dan Pembelajaran Khatulistiwa, 3(12), 1 13

[3] Kristiawan, M. \& Wulandari, Y. (2017). Strategi Sekolah dalam Penguatan Pendidikan Karakter Bagi Siswa dengan Memaksimalkan Peran Orangtua. Jurnal Manajemen, Kepemimpinan, dan Supervisi Pendidik., 2(2), 290-303.
[4] Ridwan, A. (2017). Peran Guru Agama dalam Bimbingan Konseling Siswa Sekolah Dasar. Jurnal Pendidik dan Studi Islam, 4(1), 1-13.

[5] Hadi, S. (2017). Peran Dan Tanggung Jawab Staf Sekolah Dalam Bimbingan dan Konseling Bagi Siswa. Jurnal Tatsqif, 15(2), 211222

[6] Hallen, A. (2002). Bimbingan dan Konseling. Jakarta: Ciputat Asri.

[7] Prayitno \& Erman, A. Dasar-dasar Bimbingan dan Konseling. Jakarta: Adi Mahasatya.

[8] Mappiare, A.A. (2002). Pengantar Konseling dan Psikoterapi. Jakarta: Rajawali Persada

[9] Tohirin. (2011). Bimbingan Konseling di Sekolah Madrasah. Jakarta: Raja Grafindo Persada.

[10] Kamaluddin, H. (2011). Bimbingan dan Konseling Sekolah. Jurnal Pendidikan dan Kebudayaan, 17(4).

[11] Ahmad, R. \& Syahril. (2012). Pengantar Bimbingan Konseling Jakarta: Bumi Aksara

[12] Sugiyono. (2015). Metode Penelitian Pendidikan. Bandung: Alfabeta.

[13] Firman. (2018). Analisis Data dalam Penelitian Kualitatif.

[14] Kusumawati, M.M. PN. (2017). Strategi bimbingan Konseling Bagi Siswa Yang Mengalami Ketidakmampuan/Keterbatasan Belajar. JAMBORE KONSELOR 3, 162-167.

[15] Sukardi, D.K. \& Kusmawati, D.P.E.N. (2008). Proses Bimbingan dan Konseling di Sekolah. Jakarta: Rineka Cipta.

[17] Sudarmawan, B. Peranan Guru Dalam Pelaksanaan Kegiatan Bimbingan dan Konseling di SMP Negeri 48 Kebayoran Lama. Skripsi. UIN Syarif Hidayatullah,

[18] Kaltsum, U. Pengaruh implementasi Bimbingan dan Konseling Terhadap Perilaku Delinkuen Pada Peserta Didik. Auladuna, 2(1), $1-25$.

[19] Leksono, B. B. Manajemen Bimbingan dan Konseling di sekolah Menengah Atas Negeri Karangreja Kabupaten Purbalingga. Skripsi. IAIN Purwokerto.

[20] Ariyanti, M. (2017). Peran Kepala Sekolah dalam Program Bimbingan dan Konseling di SMA Negeri 1 Jetis Bantul Yogyakarta. Skripsi. UIN Sunan Kalijaga. 